\title{
FALSOS BENS JURÍDICOS E POLÍTICA CRIMINAL DE DROGAS: UMA APROXIMAÇÃO CRÍTICA
}

Érika Mendes de Carvalho

Doutora e Pós-Doutora em Direito Penal pela Universidad de Zaragoza (Espanha). Professora Associada de Direito Penal na Universidade Estadual de Maringá (UEM). Bolsista de Produtividade em Pesquisa da Fundação Araucária de Apoio ao Desenvolvimento Científico e Tecnológico do Estado do Paraná. Coordenadora do Núcleo de Estudos Penais e da Pós-Graduação em Ciências Penais da UEM.

Gustavo Noronha de ÁviLA Doutor em Ciências Criminais pela Pontifícia Universidade Católica do Rio Grande do Sul (PUC-RS). Professor de Direito Penal e Criminologia na Universidade Estadual de Maringá. Professor do Mestrado em Ciências Jurídicas do UNICESUMAR.

\section{Resumo}

O presente estudo realiza uma aproximação crítica às incriminaçóes constantes da Lei 11.343/2006 a partir da perspectiva da teoria do bem jurídico para, primeiramente, demonstrar que - sob a ótica da tutela de bens individuais - náo respeitam o princípio da autonomia e expressam a opção do legislador por um inadmissível paternalismo penal. Já sob o enfoque da proteção de um (aparente) bem jurídico coletivo, opera a desconstrução daqueles comumente apontados como legitimadores da intervenção penal - saúde pública, segurança pública, paz pública -, seja porque não possuem qualquer realidade existencial, seja porque representam a soma de bens jurídicos individuais. Desmascara-se, ademais, a racionalidade oculta por trás da irracional proteção conferida a falsos bens jurídicos, a saber, a mera preservação da vigência normas penais incriminadoras, totalmente dissociadas da realidade concreta e forjadas para a afirmação de um punitivismo doloroso e sem limites.

\section{Palavras-chave}

Bem jurídico-penal; Lei de Drogas (Lei 11.343/2006); Paternalismo penal; Falsos bens jurídicos coletivos.

\section{Resumen}

El presente estudio realiza una aproximación crítica a las incriminaciones presentes en la Ley 11.343/2006 a partir de la perspectiva de la teoría del bien jurídico para, en 
primer lugar, demonstrar que - desde el punto de vista de la tutela de bienes individuales - no respetan al principio de la autonomía y expresan la opción del legislador por un inadmisible paternalismo penal. Por otra parte, desde el punto de vista de la protección de un (aparente) bien jurídico colectivo, opera la desconstrucción de aquellos comúnmente apuntados como legitimadores de la intervención penal - salud pública, seguridad pública, paz pública -, sea porque no poseen ninguna realidad existencial, sea porque representan la suma de bienes jurídicos individuales. Se desnuda, además, la racionalidad oculta por detrás de la irracional protección conferida a falsos bienes jurídicos, a saber, la mera preservación de la vigencia de las normas penales incriminadoras, totalmente disociadas de la realidad concreta y forjadas para la afirmación de un punitivismo doloroso y sin límites.

\section{Palabras clave}

Bien jurídico-penal; Ley de Drogas (Ley 11.343/2006); Paternalismo penal; Falsos bienes jurídicos colectivos.

\section{Introdução}

A dogmática penal trava acirrado debate, na atualidade, acerca da necessidade de se recorrer ao conceito de bem jurídico para legitimar a intervenção punitiva. Há quem defenda que essa noção mostra-se em franco declínio, já que grande parte das tipificaçôes prescinde por completo desse fundamento material. Nesse sentido, argumenta-se que seria perfeitamente admissível abrir mão do conceito de bem jurídico e optar por outras bases limitadoras e/ou legitimadoras da resposta penal ou, pelo menos, relativizar aquele em determinados casos. Noutra perspectiva, sustenta-se que o abandono da noção de bem jurídico, como base material limitadora das construçóes típicas, pode conduzir a uma arbitrariedade desmedida e perigosa, que culmina na proteção do próprio ordenamento penal, com independência dos concretos conteúdos normativos.

Inicialmente, busca-se examinar as propostas que postulam a substituição da noção de bem jurídico como referente material do delito, sob o argumento de que a referida noção encontra-se em flagrante crise e que a expansão do Direito Penal evidenciaria, de modo irremediável, que não cumpriu com a função principal a que se propunha, a saber, a limitação do espaço de criminalização.

Algumas dessas tendências doutrinárias, de matiz funcionalista, questionam precisamente a utilidade do conceito de bem jurídico, que deveria ser abandonado ou esvaziado materialmente, uma vez que fracassou na tentativa de circunscrição da amplitude do sistema normativo e não é levado em consideração no processo de elaboração das leis penais incriminadoras. 
Outras orientações doutrinárias, igualmente funcionalistas, sugerem a relativização do conceito de bem jurídico, admitindo a intervenção jurídico-penal mesmo em situações (excepcionais) onde não seja possível detectar a presença de um bem jurídico lesado ou ameaçado de lesão. Essas últimas tendências, embora não prescindam da noção de bem jurídico, acabam por aceitar a ampliação do catálogo de tipos penais em determinadas hipóteses nas quais - do ponto de vista de seus partidários - a (s) conduta (s) típica (s) não lesa $(\mathrm{m})$ ou expõe $(\mathrm{m})$ a perigo de lesão qualquer bem jurídico. Essas situaçóes seriam um sintoma da insuficiência do conceito de bem jurídico como critério material exclusivo hábil a fundamentar uma intervenção penal subsidiária e mínima e abririam espaço para a influência decisiva - e, fatalmente, inflacionária do sistema punitivo - de consideraçóes político-criminais (v.g. prevenção geral) como critérios de legitimação da criação de leis penais incriminadoras.

Por fim, são apresentadas propostas de revitalização da noção de bem jurídico como critério material suficiente para a delimitação da intervenção penal. A presença, no ordenamento jurídico-penal brasileiro, de incriminaçôes sem bem jurídico - ou ancoradas em pseudos bens jurídicos - não seria evidência da falência desse conceito, mas mostra da inconstitucionalidade do (s) tipo (s) penal (is) e sintoma de uma intervenção punitiva desarrazoada, excessiva, ilegítima e arbitrária.

O presente trabalho pretende examinar o estado atual da discussão, no Brasil, e conferir especial destaque às propostas que defendem a extirpação dos tipos penais constantes da Lei 11.343/2006 (Lei de Drogas) do ordenamento jurídico, em função da ausência de bem jurídico protegido.

\section{Conceito Material de Delito e Proteção de Bens Jurìdicos}

Do ponto de vista dogmático, o conceito de bem jurídico forjou-se como o principal referente material (de) limitador do âmbito de intervenção jurídico-penal, mesmo que durante alguns momentos históricos razóes políticas tenham motivado o abandono desse critério ou sua substituição. Ainda que nosso trabalho não se proponha a abordar a evolução história do conceito de bem jurídico e a examinar suas funçóes declaradas e ocultas, cabe aqui enfatizar que uma delas sempre foi a de tratar limitar os espaços de criminalização possíveis, com apoio também em outros critérios - constitucionais e político criminais - auxiliares (tais como os princípios da legalidade, da intervenção mínima ou da subsidiariedade, da lesividade, da culpabilidade, da proporcionalidade). Não vamos nos debruçar, nesse trabalho, na extensa e polêmica discussão acerca da legitimidade do Direito Penal como meio de solução de conflitos sociais ou de se assegurar uma coexistência social harmônica e pacífica, como sugere ainda a dogmática penal. Concordamos que a resposta punitiva não é a única e muito menos a melhor via para a tutela das relaçóes 
sociais, de interesses individuais, coletivos ou difusos ou mesmo do próprio ordenamento jurídico. Ocorre que quando a resposta punitiva se dá, faz-se necessário investigar - em termos dogmáticos, político criminais e criminológicos - seus pilares de sustentação. Sob a perspectiva dogmática, cabe examinar, inicialmente, se haveria um conceito material de delito por trás de sua difundida definição analítica (conduta típica, ilícita e culpável) e se esse conceito material se encontra edificado sobre a base da necessidade de proteção de bens jurídicos.

A função de tutela de bens jurídicos é apontada há séculos como a missão primordial do Direito Penal. Mas essa função não seria, de modo algum, exclusividade do Direito Penal. É compartilhada por outros ramos do ordenamento jurídico, de forma que tal ideia não pode ser suficiente, por si só, para identificar a função específica e própria do Direito Penal $^{1}$. Com efeito, se assumimos que inexiste diferença qualitativa entre ilícitos penais e administrativos, por exemplo, não haveria razão para sustentar que o Direito Administrativo sancionador não incorpora a noção de bem jurídico e se limita a tutelar, tão somente, funçóes da Administração. Todavia, se o Direito - e o Direito Penal em particular - não pretende figurar como um mero exercício dos cidadãos na obediência, as normas jurídicas - e, notadamente, as normas jurídico penais - devem incorporar proibiçóes e comandos de agir que tenham por objetivo a conservaçáo ou a produçáo de determinados objetos e valores inerentes às relações sociais (bens jurídicos) a fim de permiti-las e orientá-las, fomentando uma convivência pacífica e de respeito a interesses individuais e coletivos.

O bem jurídico, do ponto de vista material, pode ser definido como "todo bem, situação ou relação desejados e protegidos pelo Direito" ${ }^{2}$. Sua tutela pelo Direito Penal não é irrestrita, posto que o cumprimento de suas funçôes sociais pressupõe, algumas vezes, que seja exposto a situaçóes de perigo toleradas ou permitidas pelo próprio ordenamento jurídico. Pode-se dizer, portanto, que o Direito Penal protege bens jurídicos apenas diante de algumas formas de agressão ou de perigo particularmente intoleráveis ${ }^{3}$.

Uma das funçôes (político criminais) atribuídas ao conceito material de bem jurídico consistiria na limitação do arbítrio legislativo. É forçoso reconhecer, porém, que a “a capacidade limitativa do conceito material de bem jurídico com relação ao arbítrio do legislador penal é realmente escassa” ${ }^{4}$, pois, como observa com acerto Cerezo Mir, "o âmbito de proteção dos bens jurídicos estará determinado pelas concepções ético-sociais, jurídicas

1 GRACIA MARTÍN, Luis. Fundamentos de dogmática penal. Una introducción a la concepción finalista de la responsabilidad penal. Barcelona: Atelier, 2006, p.56-57.

2 CEREZO MIR, José. Curso de Derecho Penal español, Parte General, t. I. 5 ed. Madrid: Tecnos, 1998, p.13-14, que acrescenta que "a soma dos bens jurídicos constitui a ordem social criada e protegida pelo Direito".

3 Cf. PRADO, Luiz Regis. Bem jurídico-penal e Constituição. 5 ed. São Paulo: RT, 2011, p.110 e ss.

4 GRACIA MARTÍN, Luis, op.cit., p.57. 
e políticas dominantes" ${ }^{5}$. Consequentemente, sempre haverá uma atuação condicionada, motivada ou orientada pelas contingências sociais ou políticas, por exemplo, de um dado momento histórico ou mesmo pelo clamor midiático.

De fato, o catálogo de bens jurídicos passíveis de proteção jurídico-penal é variável e diretamente vinculado aos valores e interesses daqueles que detém o poder político, pois "os Códigos penais não protegem interesses a-históricos nem valores eternos desvinculados da estrutura social de um lugar e de um tempo concretos" ${ }^{\text {. }}$

O importante, conforme assinala Mir Puig, é que os objetos reais de tutela (realidades materiais ou imateriais) expressem uma dimensão social, de forma que sua indenidade represente "uma necessidade social" e condicione "as possibilidades de participação do indivíduo nos sistemas sociais" ". Sob a ótica jurídico-filosófica, contudo, se o Direito Penal não pretende ser mera expressão de força e de poder político ou simplesmente imposição de terror por parte do Estado, suas normas não podem estar dissociadas do respeito ao homem como pessoa. Se assim for, a positividade em conflito com o princípio material de justiça de validade a priori do respeito à dignidade da pessoa humana não possuirá qualquer força obrigatória ${ }^{8}$.

A noção de bem jurídico não se confunde com seu substrato - que, enquanto dado ontológico, não traduz qualquer juízo axiológico -, embora possa radicar em uma realidade material (v.g. vida, integridade física, patrimônio) ou imaterial (v.g. honra, saúde coletiva, intimidade). Ainda que grande parte da doutrina defina o bem jurídico como valor ou como interesse, totalmente distinto e/ou independente da realidade empírica que constitui seu substrato ${ }^{9}$, partilha-se aqui da concepção que extrai o bem jurídico a partir de sua base empírica (material ou imaterial $)^{10}$. Nessa perspectiva, reconhece-se que a noção de bem jurídico - no sentido dogmático (de lege lata), de objeto efetivamente tutelado pelo plano normativo - encontra na realidade concreta seu autêntico conteúdo e sobre esta incidem juízos de valor que selecionam os interesses merecedores de tutela penal.

Distanciar ou desvincular totalmente o conceito de bem jurídico da realidade concreta oferece riscos que a dogmática penal não pode e nem deve assumir. Isso não significa

5 CEREZO MIR, José. Curso de Derecho Penal español, Parte General, t. I, p.14, nota 6.

6 MIR PUIG, Santiago. Derecho Penal, Parte General. 9 ed. Barcelona: Reppertor, 2011, p.161.

7 MIR PUIG, Santiago. Derecho Penal, Parte General, p.163.

8 Cf. CEREZO MIR, José, op.cit., p.18.

9 ROXIN, Claus. Derecho Penal. Parte General. T. I. Fundamentos. La Estructura de la Teoría del Delito. Trad. Diego-Manuel Luzón Peña, Miguel Díaz y García Conlledo e Javier De Vicente Remesal. Madrid: Civitas, 1997, \$2, n.9, 15 e 24; JESCHECK, Hans-Heinrich; WEIGEND, Thomas. Tratado de Derecho Penal, Parte General. Trad. Miguel Olmedo Cardenete. Granada: Comares, 2002, p.275-276.

10 Cf. WELZEL, Hans. Derecho Penal alemán. Parte General. Trad. Juan Bustos Ramírez e Sérgio Yáñez Pérez. Santiago: Jurídica de Chile, 1976, p.11-15. 
dizer que bem jurídico e substrato do bem jurídico sejam a mesma coisa. São claramente diferentes: mesmo que o bem jurídico radique em uma realidade empírica (substrato material do bem jurídico) ele vai além desta última, pois incorpora uma dimensão valorativa nela ausente. Entretanto, essa dimensão valorativa não deve abandonar a realidade concreta que constitui seu sustentáculo. O Direito Penal não pode proteger valores em si, mas realidades existenciais concretas (de caráter material ou imaterial), que só alcançam o status de bens jurídicos quando apresentam valor funcional para seus titulares e para a sociedade ${ }^{11}$.

A assunção de bens jurídicos divorciados da realidade empírica pode conduzir, conforme bem adverte Mir Puig:

“à 'evaporação' do conceito de bem jurídico, ao priva-lo da referência aos concretos objetos existenciais que o Direito penal deseja proteger. $\mathrm{O}$ bem jurídico acaba, por esta via, por deixar de ser um 'bem' dotado de concreto conteúdo real, para confundir-se com a abstrata 'finalidade da lei' - como chegou a sustentar a exacerbação do conceito neokantiano de bem jurídico em um sentido meramente 'metódico-teleológico'. Isso não significa que devam ser equiparados o bem jurídico e seu substrato empírico. Pelo contrário, já se disse mais acima que um 'bem' é sempre algo mais que uma 'coisa'. Mas também é essa 'coisa', só que contemplada em seu valor funcional: o bem é uma coisa valiosa, entendendo aqui por coisa toda realidade existencial com independência de seu caráter material ou imaterial. O conceito de bem jurídico é, pois, expressão de uma relação dialética de realidade e valor"”'12.

Embora os interesses, os dados e os elementos da realidade concreta náo figurem como bens jurídicos fora do plano normativo - ao qual ascendem quando apresentam uma dimensão valorativa funcional, sob a perspectiva individual ou coletiva -, constituem sim a base sobre a qual devem se projetar os juízos valorativos. Do ponto de vista político criminal (de lege ferenda) só devem merecer a tutela penal aqueles interesses, dados, elementos ou relaçóes da realidade concreta efetivamente portadores de acentuada relevância para a própria existência do individuo ou da coletividade. Essa dimensáo social do bem jurídico deve orientar a tutela penal e fornecer a concretude material necessária à edificação do ordenamento jurídico.

É forçoso reconhecer, porém, que mesmo essa noção de bem jurídico - que conjuga suas dimensóes ontológicas e valorativas - apresenta uma reduzido - e, por vezes, discutível - papel de limitação do arbítrio do legislador penal ou de redução do exercício do

11 Cf. MIR PUIG, Santiago, op.cit., p.163.

12 MIR PUIG, Santiago, op.cit., p.163. 
poder punitivo ${ }^{13}$. Sobretudo porque se trata aqui do desempenha uma função positivaexpressa na análise do significado funcional valioso que determinados dados, interesses ou relaçôes devem apresentar para merecer a tutela penal -, mas não negativa - no sentido de excluir ou privar aqueles dados, interesses ou relaçóes do conceito de bem jurídico. Essa função negativa não poderia ser desempenhada exclusivamente pelo conceito (político criminal) de bem jurídico, mas por outros princípios limitativos do Direito Penal (v.g. intervenção mínima, fragmentariedade, proporcionalidade).

Em síntese, sustentamos que o conceito de bem jurídico, embora forjado no plano normativo (valorativo), apresenta um referencial material (ontológico), conectado à realidade existencial (material ou imaterial). O substrato empírico que serve de base ao bem jurídico não exclui a análise axiológica do sentido funcional desses elementos, dados, interesses ou relaçôes concretos sob a perspectiva individual ou coletiva. Esse 'filtro valorativo’ será responsável pela seleção dos concretos elementos, dados, interesses ou relaçóes cujo significado social ou político, extraído à luz de um determinado momento histórico, ensejará o recurso à tutela penal (subsidiária).

É difícil, porém, responder à crítica dirigida ao conceito material de bem jurídico segundo a qual a escolha dos bens merecedores de tutela penal será feita por aquele grupo social que detenha o poder político. E isso porque o substrato material do bem jurídico não impede que determinado interesse, elemento ou relação social seja erigido à categoria de bem jurídico penal e tampouco assegura a imutabilidade do catálogo de bens jurídicos protegidos pelo ordenamento jurídico penal. Logo, caberá essencialmente ao plano valorativo eleger, a partir da realidade concreta, quais interesses, dados ou relaçóes sociais devem merecer a proteção penal.

Essa realidade concreta, porém, não pode ser substituída (segundo a concepção que assumimos como ponto de partida, de cunho onto-axiológico) pela 'finalidade da lei' ou por valores sem qualquer conteúdo real ${ }^{14}$. Quando assim for, a ausência de um conteúdo real e concreto conduz à aludida 'evaporação' do conceito de bem jurídico, posto que este estará dissociado de uma referência aos objetos existenciais fundamentais que ao Direito Penal incumbe tutelar.

Realizada a seleção daqueles objetos, interesses ou relaçóes especialmente valiosos do ponto de vista social e político (processo este claramente valorativo), caberá perquirir

13 Nesse sentido, por exemplo, GRACIA MARTÍN, Luis, op.cit., p.57, MIR PUIG, Santiago, op.cit., p.163; CEREZO MIR, José, op.cit., p.14, nota 6.

14 Nesse sentido, Mir Puig assevera que "um Direito Penal protetor de bens jurídicos não tutela puros valores em si mesmos, mas realidades concretas: nenhuma proteçáo jurídico-penal mereceria o "valor vida' se não se encarnasse na vida de uma pessoa real; o Direito penal não deve proteger o 'valor vida' enquanto tal valor, mas as vidas concretas dos cidadãos $>$ mas claro que estas vidas reais não constituem bens jurídicos enquanto meros dados biológicos, mas por seu valor funcional para seus titulares e para a sociedade" (op.cit., p.163). 
o significado dogmático do interesse, dado ou relação social efetivamente tutelado pela norma penal concretamente infringida por meio da conduta humana (ação ou omissão) proibida ou ordenada. Nesse sentido, é preciso destacar que a ausência de periculosidade da conduta ou de lesão ou perigo de lesão ao bem jurídico protegido poderá, agora, elidir o injusto material da específica figura delitiva.

\section{A Crise do Conceito de Bem Jurídico: Superação ou Relativização?}

Conforme examinado, o conceito de bem jurídico se propôs originalmente, em termos dogmáticos, a limitar a extensão do poder punitivo e circunscrevê-lo à sanção de condutas (ações ou omissóes) perigosas ou lesivas a determinados interesses, elementos ou relaçóes sociais merecedores de tutela por parte do Direito Penal. Assim, o conceito material de delito consiste em vislumbrá-lo como aquela conduta que lesa ou expóe a perigo bens jurídicos fundamentais para o indivíduo e para a sociedade, representando uma grave violação de normas de determinação construídas a partir das concepçóes ético-sociais, políticas e econômicas dominantes em um determinado momento histórico.

Pois bem, na atualidade, esse conceito experimenta uma grave crise. Especialmente na Alemanha, onde a dogmática penal apresenta acentuado grau de desenvolvimento. Entre as causas aventadas para essa crise encontra-se o notório processo de expansão do Direito Penal, que implica em incremento punitivo, criação de novos bens jurídicos, ampliação da severidade na execução das penas e diminuição ou mesmo supressão de garantias penais e processuais penais ${ }^{15}$. O conceito de bem jurídico não cumpriu - argumenta-se - com suficiência e êxito sua função de limitação material do poder punitivo e essa falha seria facilmente identificada quando, justamente a pretexto de proteger novos bens jurídicos ou de conferir uma mais eficiente tutela a bens já conhecidos, ampliam-se os âmbitos de tutela ou se estende a intervenção penal a situaçôes nas quais não se identifica qualquer bem jurídico lesado ou ameaçado de lesão.

O aludido fracasso do conceito de bem jurídico é apontado como motivo para sua superação, tanto do ponto de vista dogmático (de objeto efetivamente tutelado pela norma jurídico penal concretamente infringida) quanto em seu sentido político-criminal (de objeto/relação/dado da realidade que mereça ser protegido pelo Direito Penal). Outras propostas se direcionam à relativização do dogma do bem jurídico, sem, contudo, postular sua total supressão.

A mais expressiva das propostas voltadas à superação do dogma do bem jurídico é aquela feita por Günther Jakobs. Este explica sua teoria do delito nos moldes funcionalistas

15 Cf. COSTA, Helena Regina Lobo da. Consideraçóes sobre o estado atual da teoria do bem jurídico à luz do Harm Principle. In: GRECO, Luis; MARTINS, Antonio (Orgs.). Direito Penal como critica da pena. Estudos em homenagem a Juarez Tavares por seu $70^{\circ}$ Aniversário em 2 de setembro de 2012. Madrid: Marcial Pons, 2012, op.cit., p.135. 
sistêmicos da seguinte forma: o fato delitivo representa uma "rebelião contra a norma, e a pena rechaça essa rebelião", pela dor que inflige e pela eliminação do "risco de erosão geral da vigência da norma"16 (a denominada 'prevenção geral positiva'). O importante, portanto, seria a "proteção da vigência da norma". A tese da proteção de bens jurídicos, afirma Jakobs, "ao tomar como ponto de referência um bem, arranca de um ponto de partida errôneo; pois o Direito é uma relação entre pessoas; só através destas também entram em ação os bens" ${ }^{17}$.

Como na sociedade as pessoas se vinculam através de normas, endereça-se a essas pessoas a expectativa de que suas condutas se ajustem a essas normas ('expectativa normativa'), expectativa essa que, quando frustrada pela conduta delitiva, não será abandonada, mas confirmada com a imposição de uma sanção. A vigência das normas jurídico-penais seria assegurada, de conseguinte, "por meio de uma pena imposta num procedimento formal" 18 .

A pena, segundo Jakobs, deve ser "algo mais que coação, que infligir dor", a pena "deve ser uma resposta com o conteúdo de que o ataque do autor contra a estrutura normativa da sociedade não é determinante e que essa estrutura mantém sua configuração sem modificaçôes" ${ }^{19}$. Entretanto, resta claro que, para ele, a pena é a concretização de uma resposta que confirma a vigência normativa "à custa do autor, já que este deve ressarcir à sociedade pelo dano na vigência da norma que produziu" ${ }^{20}$, e que tal ressarcimento significa a imposição, ao autor da violação da vigência normativa, de determinados "custos", através da privação de "meios de desenvolvimento" (v.g. de todos esses meios - assim, a pena de morte -, da maioria deles, durante um período de tempo - assim, a pena privativa de liberdade - ou de alguns deles - assim, a pena de multa). Com a imposição da pena, pretende-se compensar o dano que o autor produziu à vigência da norma primária

16 JAKOBS, Günther. ¿Cómo protege el Derecho Penal y qué es lo que protege? Contradicción y prevención; protección de bienes jurídicos y protección de la vigencia de la norma. Trad. Manuel Cancio Meliá. In: MAIER, Julio B. J.; CÓRDOBA, Gabriela E. (Orgs.) ¿Tiene un futuro el Derecho penal? Buenos Aires: Ad-Hoc, 2009, p.54.

17 JAKOBS, Günther, op.cit., p.54.

18 JAKOBS, Günther. Sociedade, norma e pessoa: teoria de um direito penal funcional. Trad. Maurício Antonio Ribeiro Lopes. Barueri: Manole, 2003, p.13.

19 JAKOBS, Günther, ¿Cómo protege el Derecho Penal y qué es lo que protege? Contradicción y prevención; protección de bienes jurídicos y protección de la vigencia de la norma. Trad. Manuel Cancio Meliá. In: MAIER, Julio B. J.; CÓRDOBA, Gabriela E. (Orgs.) ¿Tiene un futuro el Derecho penal? Buenos Aires: Ad-Hoc, 2009, p.56. Para Jakobs "através do mero fato de que um delito seja perseguido se mostra que se pretende manter a configuração que a sociedade teve até o momento; inclusive a mera denominação de um delito como tal delito significa sua marginalização comunicativa; portanto, é possível que exista comunicação acerca da estrutura normativa da sociedade sem a imposição de uma pena, sem dor. Todavia, uma comunicação que tenha lugar através de uma mera denominação é etérea, e isso pode não ser suficiente frente a um fato que não se esgota em uma mera afirmação contrária à vigência da norma, mas que também executa o ato que lesa a vigência, e o objetiva nesse sentido" (op.cit., p.56).

20 JAKOBS, Günter, op.cit., p.56. 
e fomentar na coletividade uma "atitude natural de fidelidade ao ordenamento jurídico" 21 (prevenção geral positiva).

Pois bem, para Jakobs o sistema penal e a imposição da pena não se orientam imediatamente à proteção de bens jurídicos - este seria apenas um "resultado mediato" e "parcial"22. O Direito Penal protege, na verdade, a vigência normativa, que encerra a expectativa de não lesão/perigo ao bem jurídico.

Em crítica à concepção de proteção de bens jurídicos, Jakobs argumenta, em síntese, que: 1) essa concepção pode abarcar tudo - "pode-se proclamar como bem jurídico também a manutenção de um determinado partido político, ou a pureza de uma raça humana, ou outros objetos, como aconteceu de facto na Alemanha da época nacionalsocialista"23; 2) o Direito "não é um muro protetor colocado ao redor dos bens, mas é uma relação entre pessoas"; 3) se o importante é a proteção de bens jurídicos, os delitos de perigo abstrato alcançam legitimidade, pois "não há nada mais efetivo que intervir quanto antes" ${ }^{24}$; 4) a tese da proteção de bens jurídicos só conta com argumentos jurídico-políticos, mas não com argumentos jurídico-dogmáticos ou teórico jurídicos; 5) a exemplo da tese da proteção das normas, só se legitima quando a sociedade cujo Direito é retratado atinge um determinado grau de evolução.

Pois bem, a proposta de superação da tese da proteção de bens jurídicos elaborada por Jakobs é a tentativa mais bem acabada de esvaziamento do conceito de bem jurídico empreendida pela dogmática penal contemporânea. É importante destacar que a tese de Jakobs não pretende oferecer limites ao poder punitivo, sob o argumento de que a escolha do conteúdo das normas penais a serem tuteladas seria uma questão política, não científica ${ }^{25}$.

Para refutar a tese de Jakobs e oferecer limites mais precisos ao poder punitivo, seria necessário que a concepção da proteção de bens jurídicos: 1) não permitisse que tudo fosse compreendido pela noção de bem jurídico, mas tão-somente dados, relaçóes e interesses que contassem como uma base sólida na realidade social concreta, excluídos sentimentos, moralismos e conceitos vazios de conteúdo; 2) que o Direito Penal não assumisse com a pretensão (irreal) de blindar os bens jurídicos de ataques e consumos inerentes à vida em sociedade, posto que aqueles não são "peças de museu”, como já destacava Welzel; 3) assumisse a pertinência das estruturas típicas de perigo abstrato, sempre que "a

21 Logo, "a pena significa uma contradição do significado do fato, e a dor da pena deve produzir prevenção geral positiva” (op.cit., p.60).

22 Assim, "Direito Penal protege a vigência da norma, e só de modo mediato e parcial também bens" (JAKOBS, G., op.cit., p.67).

23 JAKOBS, G., op.cit., p.69 e ss.

24 JAKOBS, G., op.cit., p.67.

25 JAKOBS, G. ¿Qué protege el Derecho penal: bienes juridicos o la vigencia de la norma? Trad. Manuel Cancio Meliá. Mendoza: Ediciones Jurídicas Cuyo, 2000, p.15 e ss. 
capacidade geral da ação para a colocação em perigo do bem jurídico" preenchesse com suficiência "as exigências do injusto material" sob o prisma do desvalor da ação; 4) contasse com argumentos dogmáticos, aliados aos argumentos políticos, em uma construção onto-axiológica, buscando na noção de dignidade humana um limite material inalienável à seleção do bem jurídico em matéria penal; 5) partisse necessariamente de uma construção política democrática, já que em sociedades totalitárias a proteção do arcabouço normativo não leva em consideração o conteúdo deste, do ponto de vista do respeito aos direitos fundamentais e da condição do homem como pessoa.

A tese da proteção de normas, segundo Jakobs, "retrata o Direito com maior exatidão" precisamente porque se conforma com o ordenamento tal como é, mesmo quando as normas incriminadoras se orientam à tutela de funçóes, de bens vazios de conteúdo concreto, de moralismos, de sentimentos, ou seja, mesmo quando não é possível identificar qualquer bem jurídico.

O processo de incriminação é, essencialmente, político. A partir dessa constatação, a teoria da proteção normativa sustenta que o importante é proteger a vigência normativa primária e compensar, através da imposição de uma pena, o dano produzido àquela. A tese da proteção de bens jurídicos não se orienta à proteção do ordenamento, mas de seu suporte real contemplado em seu valor funcional ${ }^{26}$.

A adoção de uma postura normativista extrema prescinde, assim, do exame do conteúdo normativo para conferir destaque à proteção do ordenamento penal, com independência de seu conteúdo valioso e sem qualquer vinculação com a realidade concreta. Não se preocupa, portanto, com a colocação de limites (onto-axiológicos) àquele conteúdo. A proteção de bens é vista como mediata e parcial.

Postulamos aqui a inversão dessa perspectiva e priorizamos a proteção de realidades existenciais (materiais ou imateriais) valiosas - e não a mera proteção do revestimento normativo (formal), do invólucro legal, -, já que uma norma que não tenha por objeto dados, relaçóes ou interesses do plano real concreto, selecionados a partir de critérios político-criminais restritivos do poder punitivo e limitados pela perspectiva de respeito à dignidade do homem como pessoa, não é materialmente Direito.

A criticada insuficiência do conceito de bem jurídico como limite material para os processos de criminalização não deve ensejar o esvaziamento daquele e sua substituição pela proteção da vigência normativa - como pretende, por exemplo, Jakobs - mas antes o reforço de suas bases concretas, de seus limites políticos em um Estado social e democrático de Direito (o único capaz de oferecer diretrizes teórico-restritivas ao poder punitivo) e a

26 Como concluir Mir Puig, "o bem é uma coisa valiosa, entendo aqui por coisa toda realidade existencial com independência de seu caráter material ou imaterial. O conceito de bem jurídico é, pois, expressão de uma relação dialética de realidade e valor" (op.cit., p.163). 
operacionalização de instrumentos constitucionais que (formalmente) declarem a inconstitucionalidade de normas penais que tutelem sentimentos, moralismos, bens incompatíveis com a Constituição democrática e social ou delitos de conduta ${ }^{27}$.

A teoria da proteção da vigência normativa proposta por Jakobs não conseguiu - e tampouco foi essa a sua pretensão - conferir limites materiais eficientes ao poder punitivo estatal, a exemplo de outras teses que rechaçam a teoria da proteção de bens jurídicos. Substituir o conceito de bem jurídico pela vigência da norma ${ }^{28}$ significa abandonar qualquer possibilidade de restrição ou delimitação do poder punitivo e, antes, corroborar cegamente o ordenamento jurídico posto.

Sem prescindir da tese da proteção de bens jurídicos, há aqueles que admitem relativizaçóes a ela. Não cabe expor aqui os variados matizes dessas concepçóes, mas tecer algumas consideraçóes sobre os argumentos que Roxin, por exemplo, expende em favor dessa relativização.

O funcionalismo teleológico roxiniano não compartilha da tese da proteção da vigência da norma, ao contrário. Segundo Roxin, "a função do Direito Penal consiste em garantir a seus cidadãos uma existência pacífica, livre e socialmente segura, sempre e quando estas metas não possam ser alcançadas com outras medidas político-sociais que afetem em menor medida a liberdade dos cidadãos" 29 . O injusto penal é construído "como lesão ou colocação em perigo de um bem jurídico" 30 , e não como desautorização da vigência da norma. Assim, "as condutas típicas são sempre afetações de bens jurídicos sob a forma de realização de riscos não permitidos criados pelos homens" ${ }^{31}$.

27 Também refutam o conceito de bem jurídico como diretriz limitadora do poder punitivo, entre outros, Stratenwerth e Amelung. O primeiro argumenta que a amplitude do referido conceito impede a precisăo de seu conteúdo, o que o leva a propor sua substituição pela noção de "relaçóes da vida como tais" e a configuração apenas de delitos de comportamento, baseados nas convicçôes homogêneas presentes em uma determinada sociedade - vide, assim, STRATENWERTH, Gunther. La criminalización en los delitos contra bienes jurídicos colectivos. In: HEFENDEHL. Roland. La teoría del bien jurídico. Trad. María Martín Lorenzo. Madrid: Marcial Pons, 2007, p.365-372. O segundo, por sua vez, entende que o bem jurídico desempenha apenas uma função de interpretação, cabendo ao procedimento legislativo democrático conferir legitimaçáo aos valores sociais no âmbito de uma sociedade essencialmente plural - cf., por exemplo, AMELUNG, Knut. El concepto ‘bien jurídico’ en la teoría de la protección penal de bienes jurídicos. In: HEFENDEHL, Roland. La teoría del bien jurídico. Trad. María Martín Lorenzo. Madrid: Marcial Pons, 2007, p.227-264.

28 E por "norma deve ser entendida a expectativa de que uma pessoa,, em uma situaçáo determinada, se comportará de uma maneira determinada" - JAKOBS, G. La imputación jurídico-penal y las condiciones de vigencia de la norma. In: GÓMEZ-JARA DÍEZ, Carlos (Ed.). Teoría de sistemas y Derecho Penal. Fundamentos y posibilidad de aplicación. Lima: ARA, 2007, p.227.

29 ROXIN, Claus. A proteção de bens jurídicos como função do Direito Penal. 2 ed. Porto Alegre: Livraria do Advogado, 2013, p.16-17.

30 ROXIN, Claus. El injusto penal en el campo de tensión entre protección de bienes jurídicos y libertad individual. In: MAIER, Julio B. J.; CÓRDOBA, Gabriela E. (Orgs.) ¿Tiene un futuro el Derecho Penal?. Buenos Aires, Ad-Hoc, 2009, p.73.

31 ROXIN, Claus, op.cit., p.74. 
Para Roxin, os bens jurídicos podem ser definidos como "circunstâncias reais dadas ou finalidades necessárias para uma vida segura e livre, que garanta todos os direitos humanos e civis de cada um na sociedade ou para o funcionamento de um sistema estatal que se baseia nestes objetivos" ${ }^{32}$. Admite, portanto, que os bens jurídicos podem ser criados pelo próprio legislador, não sendo fixados necessariamente a ele em um momento prévio à normatividade. Assume um conceito liberal, pessoal e crítico de bem jurídico, que "pretende mostrar ao legislador as fronteiras de uma punição legítima"33.

Aponta algumas hipóteses nas quais apenas uma análise mais profunda poderia extrair sua eventual compatibilidade em relação ao princípio da exclusiva proteção de bens jurídicos - assim, por exemplo, a proteção de sentimentos - e indica que são inadmissíveis "normas penais motivadas ideologicamente ou que atentam contra Direitos fundamentais e humanos"; a mera transcrição das finalidades da lei tampouco fundamentaria um bem jurídico; atentados contra a moral ou contra a própria dignidade humana não lesam um bem jurídico, assim como também não afetam um bem jurídico as incriminaçôes de tabus e as autolesões conscientes e não tutelam qualquer bem jurídico as leis penais simbólicas e cujos objetos de proteção sejam abstraçóes vagas e incompreensíveis ${ }^{34}$.

Recentemente, defende uma "moderada" ${ }^{5}$ relativização da teoria da proteçáo de bens jurídicos, apresentando três esferas onde a proteção penal seria legítima, ainda que nelas não se pudesse vislumbrar um bem jurídico, a saber, a proteção de embriôes, de plantas, de animais e da vida das geraçóes futuras ${ }^{36}$.

Cabe alertar, por um lado, que essa relativização divisada na concepção de Roxin ocorre, em parte, porque esta concebe o bem jurídico como um valor ou como uma finalidade, distintos de sua base real concreta, o que acaba por conduzir o bem jurídico a um processo de "espiritualização" e "evaporação", conforme destaca Mir Puig, ao "privá-lo da referência aos concretos objetos existenciais que o Direito Penal deseja proteger" ${ }^{37}$. Se atentarmos precisamente para tais bases concretas, poderemos divisar com maior possibilidade de êxito o bem jurídico tutelado (v.g. patrimônio genético, meio ambiente) ou, ante sua ausência, postularmos a consequente descriminalização.

32 ROXIN, Claus. A proteção de bens jurídicos como função do Direito Penal, p.18-19.

33 ROXIN, Claus, op.cit., p.20.

34 ROXIN, Claus, op.cit., p.20-25.

35 Vide COSTA, Helena Regina Lobo da, op.cit., p.137, quem sustenta, com razão, que "quando admite a criminalização de âmbitos sem qualquer bem jurídico subjacente, Roxin acaba por possibilitar, ainda que implicitamente, o alargamento de tais âmbitos ou a justificação de novos âmbitos de criminalização sem bem jurídico. Com isso, ao fim, o autor enfraquece o conceito, pois relativiza sua aplicaçâo".

36 Cf. ROXIN, Claus. ¿Es la protección de bienes jurídicos una finalidad del Derecho Penal? In: HEFENDEHL. Roland. La teoría del bien jurídico. Madrid: Marcial Pons, 2007, p.443-458.

37 MIR PUIG, Santiago, op.cit., p.163. 
De outra parte, embora critique que muitas vezes o bem jurídico protegido "tenha se desvanecido sob a pluma de um legislador desorientado, em conceitos gerais vagos" e que "não poucas vezes também a jurisprudência, em um cuidado exagerado de Estado de direito - por exemplo, no Direito penal do tráfico de drogas - tenha ignorado as diferenciaçôes dogmáticas existentes entre os atos preparatórios, a tentativa e a consumação, ou entre a autoria e a participaçáo", conclui Roxin que "não se deve afrontar tais defeitos fazendo com que o Direito penal se retire desses âmbitos" 38 , mas, pelo contrário, fortalecê-los do ponto de vista de seu cultivo dogmático. Contudo, defende-se aqui - no caso do Direito Penal do tráfico de drogas - precisamente a retirada da intervenção jurídico penal e não seu fortalecimento à custa de adaptaçôes forçadas de categorias dogmáticas e, especialmente, da relativização da teoria da proteção de bens jurídicos.

\section{Lei de Drogas e Falsos Bens Jurídicos: A (Ausência) de Bem Jurídico como Limite Material à Intervenção Penal}

A tese da exclusiva proteção de bens jurídicos vem sendo paulatinamente relativizada em alguns âmbitos da intervenção penal sob o argumento de que nem sempre é possível detectar um bem jurídico protegido, o que demonstraria a fragilidade desse (suposto) limite material ao poder punitivo do Estado.

Especificamente em matéria de política de drogas, o Estado se vale do Direito Penal como um instrumento de controle social hábil à proteção de um discutível bem jurídico de caráter coletivo, que seria lesado ou ameaçado de lesão com a realização das condutas típicas constantes da Lei 11.343/06: a saúde pública.

No caso da posse de drogas para consumo pessoal, tipificada no artigo 28 da Lei 11.343/2006, tem-se um exemplo inconteste de um Direito Penal paternalista, cujos estreitos limites são detectados por Schünemann não apenas a partir "do postulado da autonomia da pessoa, mas também de sua inaptidão para proteger bens jurídicos"39. $\mathrm{O}$ legislador, na atualidade, tende a "querer estabelecer um Direito penal paternalista, onde o autor é protegido de si mesmo", o qual, porém, não preenche, "em muitos casos, por sua inidoneidade para a proteção de bens jurídicos, os requisitos mínimos do Direito penal e, por isso, já é ilusório por razóes constitucionais” ${ }^{40}$.

O recurso a um bem jurídico de caráter coletivo para a criminalização de condutas associadas às drogas acaba por mascarar o problema central da decisão pela intervenção penal nessas hipóteses: a ausência de um autêntico bem jurídico que a legitime.

38 ROXIN, Claus. Sistema del hecho punible/1. Acción e imputación objetiva. Buenos Aires: Hammurabi, 2013, p.481.

39 SCHÜNEMANN, Bernd. El sistema de la teoría del delito. In: SCHÜNEMANN, Bernd. Derecho penal contemporáneo. Sistema y desarrollo. Peligro y límites. Trad. José Milton Peralta. Buenos Aires: Hammurabi, 2010, p.60.

40 SCHÜNEMANN, Bernd, op.cit., p.61. 
Na Lei de Drogas, os tipos ali elencados são comumente apontados pela doutrina como orientados à proteção da saúde pública. Se prescindirmos desse bem jurídico coletivo, supostamente afetado pelas condutas previstas nos referidos tipos penais e, como sugere Luis Greco, "trabalharmos unicamente com bens jurídicos individuais, em especial com a integridade física de quem recebe o tóxico, transformando esses crimes em crimes de perigo abstrato", seria possível, primeiramente, vislumbrarmos "a criticabilidade da proibição, que tutela um bem jurídico individual mesmo contra a vontade de seu titular" e, além disso, deslegitimarmos a absurda sanção cominada, "pois se o tráfico de tóxico nada mais é do que uma conduta que gera um perigo abstrato de lesão à integridade física, essa conduta não pode sofrer pena mais grave do que a do respectivo crime de lesão, no caso de lesóes corporais" ${ }^{41}$, sancionadas em sua forma leve com pena de detenção de três meses a um ano.

Uma estratégia para escancarar o absurdo desse paternalismo penal expresso na Lei de Drogas seria, portanto, reconduzir os tipos a bens jurídicos individuais - tais como a vida e a integridade física dos dependentes químicos, por exemplo - e abolir a referência a um (aparente) bem coletivo - como a saúde pública (soma das várias integridades físicas individuais). Em não se lançando mão dessa via, interpreta-se os tipos da Lei de Drogas como crimes de lesão ou de perigo concreto a um bem jurídico coletivo. E a saúde pública seria o bem jurídico coletivo mais frequentemente apontado como ofendido pelas condutas típicas ali incriminadas.

Logo, uma crítica às incriminaçóes constantes da Lei de Drogas a partir da perspectiva da teoria do bem jurídico deve, primeiramente, demonstrar que a incriminaçáo daquelas condutas - sob a ótica da tutela de bens individuais - não respeita o princípio da autonomia e expressa a opçáo do legislador por um inadmissível paternalismo penal ${ }^{42}$ (especialmente no caso do art. 28) ${ }^{43}$. E deve também demonstrar que essa intervenção punitiva não tem qualquer possibilidade de êxito, do ponto de vista da prevenção, para alcançar a proteção pretendida.

41 GRECO, Luís. Modernização do Direito Penal, bem juridicos coletivos e crimes de perigo abstrato. Rio de Janeiro: Lumen Juris, 2011, p.95.

42 Sobre o tema, vide, entre outros, MILL, John Stuart. Sobre la libertad. Trad. Pablo de Azcárate. 3 ed. Madrid: Alianza Editorial, 2013; DWORKIN, Gerald. Paternalismo: algumas novas reflexốes. Trad. João Paulo Orsini Martinelli. Revista Justiça e Sistema Criminal, v.4, nº 7, p.71-80, jul./dez. 2012; SCHÜNEMANN, Bernd. A crítica ao paternalismo jurídico-penal - um trabalho de Sísifo? Trad. Luís Greco. Revista Justiça e Sistema Criminal, v.4, n 7, jul/dez. 2012, p.47-70; HIRSCH, Andrew Von. El concepto de bien jurídico y el principio del daño. In: HEFELDEHL, Roland. La teoría del bien jurídico. Trad. María Martín Lorenzo. Madrid: Marcial Pons, 2007, p.47-48; GRECO, Luís. A crítica de Stuart Mill ao paternalismo. Revista Justiça e Sistema Criminal, v.4, n 7, p.81-92, jul./dez. 2012.

43 Mas a adoção dessa perspectiva, em contrapartida, poderia - especialmente no Brasil, que incrimina a indução, o auxílio e a instigação ao suicídio - legitimar a incriminação de condutas como o tráfico (art.33). 
Já sob o enfoque da tutela de um bem jurídico coletivo, deve operar precisamente para a desconstruçáo daqueles comumente apontados como legitimadores da intervenção penal - saúde pública, segurança pública, paz pública -, seja porque não possuem qualquer realidade existencial (são vazios, estéreis), seja porque representam a soma de bens jurídicos individuais.

O Direito Penal de drogas representa, conforme assinala Schünemann, "o núcleo duro do Direito Penal paternalista" ${ }^{44}$, hoje em franca expansão. Para driblar as críticas endereçadas a dispositivos que se orientam a proteger o individuo de si mesmo (paternalismo direto), são forjados bens jurídicos coletivos (v.g. saúde pública) como "pseudojustificação de antecipaçóes intoleráveis da proteção de bens jurídicos individuais" ${ }^{45}$. Porém, a mera soma de bens jurídicos individuais não pode ser suficiente para legitimar a existência de um bem jurídico coletivo ou transindividual que, nas hipóteses do Direito Penal de drogas, disfarça a inexistência de realização de perigo concreto ou de lesão à integridade física individual e a ausência de periculosidade intrínseca às condutas incriminadas.

Interpretados como delitos de perigo abstrato a bens jurídicos individuais, certos tipos penais da Lei 11.343/2006 não resistem à crítica de que se apoiam sobre os pilares de um "paternalismo duro e direto", que não consegue ser ocultado mesmo "por trás do suposto bem coletivo saúde pública” ${ }^{4}$. Sob essa perspectiva, o problema não seria propriamente a técnica de construção dos referidos tipos penais - como delitos de perigo abstrato -, mas sim a ausência de periculosidade às condutas criminalizadas e de justificação para incorporação de tipos penais puramente paternalistas.

Segundo Schünemann ${ }^{47}$, os tipos penais elaborados para prevenir autolesôes por parte do titular do bem jurídico recebem quatro críticas penais, a saber: 1) não atingem a sociedade, já que não produzem qualquer dano social ou lesão a um bem jurídico alheio ou coletivo; 2) a cominaçấo de uma pena e sua aplicaçẫo produzem, em geral, mais danos do que benefícios à pessoa afetada ${ }^{48}$; 3) a reprovação jurídico-penal dirigida ao próprio

44 SCHÜNEMANN, Bernd. A crítica ao paternalismo jurídico-penal - um trabalho de Sísifo? Trad. Luís Greco. Revista Justiça e Sistema Criminal, v.4, nº 7, jul/dez. 2012, p.55, especialmente p. 56 e ss. O autor destaca que "a mais intensa e aguda forma de paternalismo se manifesta nos tipos penais da Lei de Entorpecentes (\$29 e ss., BtMG), cuja finalidade é proteger cada cidadão individual da tentação das drogas" (op.cit., p.57).

45 SCHÜNEMANN, Bernd. A crítica ao paternalismo jurídico-penal - um trabalho de Sísifo? Trad. Luís Greco. Revista Justiça e Sistema Criminal, v.4, nº 7, jul/dez. 2012, p.59.

46 Conforme demolidora crítica de SCHÜNEMANN, Bernd, op.cit., p.59.

47 Vide SCHÜNEMANN, Bernd, op.cit., p.60.

48 Destaca Hassemer, nessa perspectiva, que "o mercado, os produtos, os consumidores - todos eles, devido ao Direito penal das drogas, se subtraem a todo e qualquer controle sólido da política de saúde do estado. As máos pesadas do Direito penal, que dominam esse campo, são incapazes de propiciar qualquer regulamentaçáo". Logo, opina, "pesa na conta da proibição penal as mortes e enfermidades de pessoas, devido ao consumo de substâncias cheias de impurezas, porquanto não submetidas a qualquer controle. 
titular do bem jurídico parece ser moralmente inadequada; 4) a cominação da pena é ineficaz, já que não atinge fins de prevenção geral ${ }^{49}$. A estas objeçôes se soma outra, de cunho jurídico-filosófico, vinculada à filosofia da liberdade e baseada no conceito de autonomia da pessoa, que refuta o emprego do Direito para alcançar objetivos paternalistas.

Quanto à configuração de tipos penais de perigo abstrato para a proteção de bens jurídicos de terceiros (paternalismo jurídico-penal indireto), entendemos que tampouco estaria legitimada a antecipação da intervenção penal. Mesmo quando se argumenta que, nesses casos, seria viável uma proteção penal de 'verdadeiros bens jurídicos de terceiros', reconhece-se que não estão "nem um pouco claros os pressupostos sob os quais se pode antecipar a tutela de um bem jurídico por meio de delitos de perigo abstrato" ${ }^{50}$. E um dos problemas seria encontrar o verdadeiro bem jurídico a fundamentar tais incriminaçóes. Aventa-se, nesse sentido, o chamado sistema social estatal, mas o próprio Schünemann reconhece a fragilidade desse argumento para criar um bem jurídico específico merecedor de tutela penal ${ }^{51}$.

Também sob o enfoque de um bem jurídico coletivo as incriminaçóes do Direito Penal de drogas recebem fortes críticas. São intentos de ocultar a antecipação da intervenção punitiva que aniquila a autonomia individual, acobertando-a sob a égide de um suposto bem coletivo. A ofensa a esse aparente bem coletivo (v.g. saúde pública, segurança pública) justificaria a intervenção penal e burlaria a violação aos princípios da ofensividade - já que estaríamos ante 'delitos de lesão' - e da proporcionalidade, violaçóes estas que ficam complemente escancaradas quando vinculamos tais incriminaçóes com bens jurídicos individuais. Assim, a manifesta desproporcionalidade das sançóes cominadas ao tráfico de drogas (reclusão de cinco a quinze anos, e pagamento de quinhentos a mil e quinhentos dias-multa - art.33, Lei 11.343/2006) quando comparadas às lesóes corporais gravíssimas (sancionadas com reclusão, de dois a oito anos - art.129, $2^{\circ}, \mathrm{CP}$ ) seria,

Também o perigo da infecção com AIDS, através do compartilhamento de seringas, deve ser debitado nessa conta" (HASSEMER, Winfried. Descriminalização dos crimes de drogas. Trad. Carlos Eduardo de Oliveira Vasconcelos. In: WINFRIED, Hassemer. Direito Penal. Fundamentos, Estrutura, Política. Porto Alegre: Sergio Antonio Fabris, 2008, p.329).

49 Cético em relação à possibilidade de atendimento, pelo Direito Penal, de demandas preventivas, mostrase, por exemplo, HASSEMER, Winfried. Direito Penal simbólico e tutela de bens jurídicos. Trad. Carlos Eduardo de Oliveira Vasconcelos. In: HASSEMER, Winfried. Direito Penal. Fundamentos, estrutura, politica. Porto Alegre: Sergio Antonio Fabris, 2008, p.227-229.

50 SCHÜNEMANN, Bernd, op.cit., p.68.

51 Analisando o citado argumento, Schünemann pondera que "qualquer condução de vida pouco saudável (como o consumo exagerado de carne ou uma vida sedentária) parece ser lesiva ao sistema social; por outro lado, o sistema social é, na verdade, sobrecarregado principalmente pelos cidadáos que, por viverem de modo extremamente saudável, chegam a uma idade avançada" concluindo que "o argumento referido ao sistema social pode, assim, ser usado em qualquer sentido e é por isso mesmo imprestável" (op.cit., p.68). 
acintosamente, legitimada pela 'lesão' (e não perigo abstrato) a um bem jurídico coletivo (saúde pública) $)^{52-53}$.

A teoria do bem jurídico não deve, porém, ser empregada para legitimar intervençôes desproporcionais. Além disso, os bens jurídicos coletivos não podem ser 'cartas na manga' de um legislador ávido por justificar seus excessos.

Ante a ausência de um bem jurídico hábil a fundamentar tais incriminaçóes, cabe indagar sobre os motivos que estão por trás dessa intervenção punitiva, exemplo claro de um tipo penal de autor ${ }^{54}$. Delitos sem bem jurídico - ou delitos de comportamento, segundo Hefendehl - são manifestaçóes de um punitivismo inadmissível, que se edifica sobre bases dogmáticas incertas - a presença de uma 'convicção enraizada da obrigatoriedade da norma de comportamento'55 - e questionáveis ${ }^{56}$.

\section{Drogas e Proibicionismo}

As drogas são tema recorrente dentre as discussões criminológicas, especialmente nas vertentes críticas. Por outro lado, são raras as tentativas de aproximaçóes entre essa perspectiva e as dogmáticas (críticas). Dentro da ideia defendida por Zaffaroni de uma criminologia cautelar ${ }^{57}$, que visa prevenir massacres estatais, é possível pensarmos na utilização

52 Adverte-se que "é preciso cuidado com pseudobens jurídicos coletivos. Falar em saúde ou incolumidade pública, por ex., esconde os déficits de legitimidade de antecipaçóes da tutela penal” (GRECO, Luís. Modernizaçâo do Direito Penal, bem jurídicos coletivos e crimes de perigo abstrato. Rio de Janeiro: Lumen Juris, 2011, p.97).

53 Com o propósito de esquivar as críticas, são apontados danos remotos ou consequências indiretas advindas das condutas criminalizadas (v.g. sensação de insegurança despertada na coletividade), o que igualmente não oferece supedâneo legítimo para se forjar um bem jurídico coletivo, nem mesmo segundo a teoria da imputação objetiva, posto que não são abarcadas pelo fim de proteção da norma. De conseguinte, "pode-se, assim, formular a diretriz de que a menção a danos remotos náo basta para fundamentar um bem juridico coletivo" (GRECO, Luís, op.cit., p.53).

54 Discorrendo sobre os problemas de legitimidade do artigo 12 da então vigente Lei 6.368/1976 - hoje, artigo 33 da Lei 11.343/2006 - notadamente sua fundamentação em uma concepção de tipos de autor, Luís Greco extrai consequências para sua interpretação, defendendo que só deve ser aplicado nas hipóteses de habitualidade e intuito de lucro, elementares típicas adicionais não indicadas expressamente - vide GRECO, Luis Tipos de autor e lei de tóxicos, ou: interpretando democraticamente uma lei autoritária. Revista Brasileira de Ciências Criminais, São Paulo, Revista dos Tribunais, n 43, 2003, p.226 e ss., especialmente p.235.

55 HEFENDEHL, Roland. El bien jurídico como eje material de la norma penal. In: HEFENDEHL, Roland. La teoría del bien jurídico. Trad. María Martín Lorenzo. Madrid: Marcial Pons, 2007, p.190-191.

56 Criticamente, sustenta Luís Greco que "o critério proposto por Hefendehl - a existência de uma convicção enraizada da obrigatoriedade da norma de comportamento em questão - parece-me, entretanto, bastante duvidoso, em especial porque ele prova demais: esse critério permite criminalizar o adultério, a troca de casais e muitos outros comportamentos sexualmente desviantes" (GRECO, Luís. Modernização do Direito Penal, bem jurídicos coletivos e crimes de perigo abstrato. Rio de Janeiro: Lumen Juris, 2011, p.55).

57 Cf. ZAFFARONI, Eugênio Raúl. A Palavra dos Mortos - Conferências de Criminologia Cautelar. São Paulo: Saraiva, 2012. 
da potência crítica também aos argumentos (ditos) duros. Desta forma, seria possível teorizar em um sentido de redução de dores.

Depois de mais de 30 anos de políticas latino-americanas pautadas pela guerra às drogas promovida, especialmente, pelos Estados Unidos da América ${ }^{58}$, o século XXI viu a tendência revisionista da repressão ganhar espaço. Esta tendência redundou, inclusive, na edição de nossa Lei 11.343/2006 e a dita despenalização das condutas do usuário. Isto, por óbvio, não excluiu a necessidade de discussão quanto ao proibicionismo direcionado ao traficante.

Thiago Rodrigues traz importante contextualização do proibicionismo enquanto tendência e, não só, de realidade concreta:

Como tônica da Proibição, a guerra às drogas jamais se aproximou da meta em erradicar o negócio e o consumo de psicoativos no mundo. $\mathrm{O}$ caráter militar assumido pela luta internacional contra as drogas ilícitas deve ser encarado não como uma inovação completa do proibicionismo, mas sim como a transposiçáo para o plano internacional da lógica coercitiva e policial de controle social consolidada localmente pela via da repressão a consumidores e negociantes de substâncias psicoativas. Com isso, afirma-se que a dimensão diplomático-militar assumida pela Proibiçâo é um desdobrar das táticas de controle social brotadas no início do século XX que forja uma inusitada modalidade de prevenção geral internacional. Questionado como solução universal para a questão do comércio e uso de psicoativos, o proibicionismo vem sendo alvo de críticas que procuram apontar saídas alternativas e novos percursos que prescindam da condenação e da criminalização como caminho para lidar com as drogas, substâncias envoltas em hábitos e práticas que se apresentam, aos olhos de cada vez mais observadores, como não suprimíveis ou incontornáveis ${ }^{59}$.

Os efeitos das políticas proibicionistas são bastante concretos e significam sangue derramado. Além disso, são inegáveis os reflexos em nossas hiperinflacionadas taxas de encarceramento, bem como nos homicídios, especialmente os de jovens e negros. Conforme Vera Guilherme e Gustavo Ávila:

Uma das recrudescências trazidas pela lei 11.343/06 é irrelevante para o universo de autores preocupados com os usuários: por trás de seu discurso universalista, esconde a questão social envolvida na determinação de quem serão os encarcerados. Os encarcerados serão os traficantes, marcados por uma definição de classe social e de sua incapacidade ou pouca

58 DEL OLMO, Rosa. A América Latina e sua Criminologia. Rio de janeiro: Revan, 2004; DE CASTRO, Lola Aniyar. Criminologia da Libertação. Rio de Janeiro: Revan, 2005, p. 171-173.

59 RODRIGUES, Thiago. Drogas, proibição e abolição das penas. In: PASSETTI, Edson (Coord.). Curso livre de abolicionismo penal. $2^{a}$ ed. Rio de Janeiro: Revan, 2012, p. 141. 
capacidade para consumo de bens. A princípio, a questão do usuário estaria resolvida no que se refere ao seu pior medo - o encarceramento ${ }^{60}$.

Ruggiero $^{61}$ refere às dificuldades em classificar, cientificamente, o termo "droga". Náo raro, tal tentativa de etiquetamento está amparada em avaliaçóes políticas e, especialmente, morais. Dessa forma, "a palavra 'droga' carrega consigo uma noção de norma e de proibição; ela faz alusão a algo a que devemos manter distância: indica uma separação social. Por essa razão, 'droga' não é um conceito descritivo, mas avaliativo: é uma senha que implica automaticamente uma proibição" ${ }^{2}$.

Além do mais, sabemos, existem muitas distorçóes em como é percebido o vício por parte do senso comum. Neste sentido, as pesquisas de Carl Hart têm sistematizado os equívocos que também alimentam o proibicionismo.

Um dos principais pilares da argumentação relativa à saúde pública é o efeito de adição derivado da utilização das substâncias (consideradas) ilícitas. Existem pesquisas demonstrando que mais de 75\% dos usuários de "drogas" - seja o álcool, remédios ou as ilegais - não enfrentam o problema do vício ${ }^{63}$. Há mais de duas décadas, tem sido demonstrado que apenas são acometidos pelas chamadas "compulsóes" entre 10 e $25 \%$ daqueles que experimentam até as substâncias consideradas mais "pesadas", como heroína e rrack $^{64}$.

Além disso, as tradicionais pesquisas envolvendo ratos e a necessidade de dopamina, causada especialmente pela cocaína, também estão sendo questionadas. Isto porque, quando os roedores são colocados em um ambiente onde não existe apenas uma alavanca que libera uma nova dose da substância, o uso tende a diminuir sensivelmente ${ }^{65}$. Ou seja: os fatores ambientais/sociais são determinantes para a adição em "drogas"66.

Como sabemos, não é legítimo ao Direito Penal proteger bens jurídicos fundados essencialmente em preceitos morais, sob pena de aproximar-se muito daquilo que diz combater ${ }^{67}$. A proteção irracional ao falso bem jurídico-penal saúde pública possui uma racionalidade oculta: "os mortos existem não pelo uso de drogas feitas ilícitas, mas sim por uma política criminal de extermínio da população jovem, negra e pobre da nossa cidade" ${ }^{68}$.

60 GUILHERME, Vera M.; ÁVILA, Gustavo Noronha de. Abolicionismos Penais. Rio de Janeiro: Lumen Juris, 2015, p. 30.

61 RUGGIERO, Vincenzo. Crimes e Mercados - Ensaios e Anticriminologia. Rio de janeiro: Lumen Juris, 2008, p. 81.

62 RUGGIERO, Vincenzo, op.cit., p.81.

63 HART, Carl. Um Preço Muito Alto. Rio de Janeiro: Zahar, 2014, p. 23.

64 HART, Carl, op.cit., p.23.

65 HART, Carl, op.cit., p. 95-100.

66 Cf. HART, Carl, op.cit., p.95 e ss.

67 RUGGIERO, Vincenzo. Crimes e Mercados - Ensaios e Anticriminologia. Rio de janeiro: Lumen Juris, 2008, p. 81-82.

68 ZACCONE, Orlando D’Elia Filho. Indignos de Vida. Rio de Janeiro: Revan, 2015, p. 266. 
Assim, o ramo jurídico-penal acaba por legitimar um verdadeiro genocídio, chamado de "guerra às drogas". Em meio ao fogo cruzado, vidas de policiais, "traficantes" e inocentes são ceifadas em um ciclo (aparentemente) infindável de dores e sofrimento. Os fins declarados são a proteção da saúde pública ou da segurança pública, porém, os resultados desse fenômeno chamado proibicionismo são vergonhosos.

No Brasil, especialmente, temos aquilo que Zaccone define como "forma jurídica de extermínio de traficantes", os chamados "autos de resistência":

"Se no período 2001/2011 contabilizamos mais de 10 mil pessoas mortas a partir de açôes policiais em nosso estado, podemos afirmar que uma parte significativa dessas mortes foi legitimada no marco de uma 'guerra às drogas'. Não podemos afirmar, no entanto, se neste mesmo período tivemos o mesmo número de pessoas mortas pelo consumo destas substâncias proibidas" ${ }^{\circ}$.

A constatação é melancólica: temos uma guerra sem sentido algum. Derramamos sangue sem justificativa racionalmente demonstrável por quaisquer das ciências criminais: dogmática, política criminal ou criminologias. É necessária a revisão urgente dos esforços de proteção a um bem jurídico inexistente, cujos resultados no sentido preventivo são risíveis.

\section{Conclusões}

Apenas a partir da teoria do bem jurídico como fundamento material da criaçáo de normas penais incriminadoras seria possível desconstruir intervençóes punitivistas alheias à realidade concreta, tal como se observa nas criminalizaçóes referentes às drogas.

As tentativas de substituição da teoria do bem jurídico não lograram fornecer limites materiais ao poder punitivo estatal.

Nos delitos constantes da Lei 11.343/2006 (Lei de Drogas), as criminalizaçóes são vinculadas a um suposto bem jurídico, a saúde pública. Trata-se, porém, de um falso bem jurídico-penal. O recurso a bens jurídicos aparentes, de natureza coletiva, encobre uma antecipação indevida da atuação do Direito Penal e uma inadmissível ingerência na autonomia individual.

A ausência de um autêntico bem jurídico não é, contudo, sintoma da deficiência desse referencial material, mas manifestação de uma intervenção penal ilegítima, arbitrária e desproporcional.

Criminalizaçóes sem bem jurídico significam, em verdade, mera tutela da própria vigência normativa, com independência de suas bases concretas (materiais ou imateriais)

69 ZACCONE, Orlando D’Elia Filho. Indignos de Vida. Rio de Janeiro: Revan, 2015, p. 266. 
relacionadas à vida em sociedade. Por essa razão, uma das mais relevantes funçôes assinaladas à teoria do bem jurídico é precisamente desmascarar falsos bem jurídicos ${ }^{70} \mathrm{e}$, consequentemente, desnudar a desnecessidade da intervenção jurídica.

\section{Referências}

AMELUNG, Knut. El concepto 'bien jurídico' en la teoría de la protección penal de bienes jurídicos. In: HEFENDEHL, Roland. La teoría del bien jurídico. Trad. María Martín Lorenzo. Madrid: Marcial Pons, 2007, p.227-264.

CEREZO MIR, José. Curso de Derecho Penal español, Parte General, t. I. 5 ed. Madrid: Tecnos, 1998.

COSTA, Helena Regina Lobo da. Consideraçóes sobre o estado atual da teoria do bem jurídico à luz do harm principle. In: GRECO, Luís; MARTINS, Antonio (Orgs.). Direito Penal como crítica da pena. Estudos em Homenagem a Juarez Tavares por seu $70^{\circ}$ aniversário em 2 de setembro de 2012. Madrid: Marcial Pons, 2012, p.133-149.

DE CASTRO, Lola Aniyar. Criminologia da Libertação. Rio de Janeiro: Revan, 2005.

DEL OLMO, Rosa. A América Latina e sua Criminologia. Rio de janeiro: Revan, 2004.

DWORKIN, Gerald. Paternalismo: algumas novas reflexôes. Trad. João Paulo Orsini Martinelli. Revista Justiça e Sistema Criminal, v.4, n 7, p.71-80, jul./dez. 2012.

GRACIA MARTÍN, Luis. Fundamentos de dogmática penal. Una introducción a la concepción finalista de la responsabilidad penal. Barcelona: Atelier, 2006.

- Prolegômenos para a luta pela modernização e expansáo do Direito Penal e para a crítica do discurso de resistência. Trad. Érika Mendes de Carvalho. Porto Alegre: Sérgio Antonio Fabris, 2005.

GRECO, Luís. Modernização do Direito Penal, bens jurídicos coletivos e crimes de perigo abstrato. Rio de Janeiro: Lumen Juris, 2011.

A crítica de Stuart Mill ao paternalismo. Revista Justiça e Sistema Criminal, v.4, $\mathrm{n}^{\circ} 7$, p.81-92, jul./dez. 2012.

. Tipos de autor e lei de tóxicos, ou: interpretando democraticamente uma lei autoritária. Revista Brasileira de Ciências Criminais, São Paulo, Revista dos Tribunais, $\mathrm{n}^{\circ} 43,2006$.

GUILHERME, Vera M.; ÁVILA, Gustavo Noronha de. Abolicionismos Penais. Rio de Janeiro: Lumen Juris, 2015.

70 Assim, GRECO, Luís, op.cit., p.35. 
HART, Carl. Um Preço Muito Alto. Rio de Janeiro: Zahar, 2014.

HASSEMER, Winfried. Direito Penal. Fundamentos, estrutura, politica. Trad. Carlos Eduardo de Oliveira Vasconcelos. Porto Alegre: Sérgio Antonio Fabris, 2008, p.209-230.

HEFENDEHL, Roland. El bien jurídico como eje material de la norma penal. In: HEFENDEHL, Roland. La teoría del bien jurídico. Trad. María Martín Lorenzo. Madrid: Marcial Pons, 2007, p.179-196.

HIRSCH, Andrew Von. El concepto de bien jurídico y el principio del daño. HEFENDEHL, Roland. La teoría del bien jurídico. Madrid: Marcial Pons, 2007, p.37-52.

IENNACO, Rodrigo. Bem jurídico e perigo abstrato: um desenho hermenêutico da ofensividade. Belo Horizonte: D’Plácido, 2014.

JAKOBS, Günther. ¿Cómo protege el Derecho Penal y qué es lo que protege? Contradicción y prevención; protección de bienes jurídicos y protección de la vigencia de la norma. Trad. Manuel Cancio Meliá. In: MAIER, Julio B. J.; CÓRDOBA, Gabriela E. (Orgs.) ¿Tiene un futuro el Derecho Penal? Buenos Aires: Ad- Hoc, 2009, p.53-71. . La imputación jurídico-penal y las condiciones de vigencia de la norma. In: GÓMEZ-JARA DÍEZ, Carlos (Ed.). Teoria de sistemas y Derecho Penal. Fundamentos y posibilidad de aplicación. Lima: ARA, 2007.

. Sociedade, norma e pessoa: teoria de um Direito Penal funcional. Trad. Maurício Antonio Ribeiro Lopes. Barueri: Manole, 2003.

- ¿Qué protege el Derecho penal: bienes jurídicos o la vigencia de la norma? Trad. Manjel Cancio Meliá. Mendoza: Ediciones Jurídicas Cuyo, 2000.

JESCHECK, Hans-Heinrich; WEIGEND, Thomas. Tratado de Derecho Penal, Parte General. Trad. Miguel Olmedo Cardenete. Granada: Comares, 2002.

MILL, John Stuart. Sobre la libertad. Trad. Pablo de Azcárate. 3 ed. Madrid: Alianza Editorial, 2013.

MIR PUIG, Santiago. Derecho Penal, Parte General. 9 ed. Barcelona: Reppertor, 2011.

PASCHOAL, Janaína Conceição. Constituição, Criminalização e Direito Penal mínimo. São Paulo: RT, 2003.

PRADO, Luiz Regis. Bem jurídico-penal e Constituição. 5 ed. São Paulo: RT, 2011.

RODRIGUES, Thiago. Drogas, proibição e abolição das penas. In: PASSETTI, Edson (Coord.). Curso livre de abolicionismo penal. $2^{\text {a }}$ ed. Rio de Janeiro: Revan, 2012, p. $140-152$.

ROXIN, Claus. A proteção de bens jurídicos como função do Direito Penal. 2 ed. Trad. Nereu José Giacomolli e André Luís Callegari. Porto Alegre: Livraria do Advogado, 2013. 
. Sistema del hecho punible/1. Acción e imputación objetiva. Buenos Aires: Hammurabi, 2013.

. El injusto penal en el campo de tensión entre protección de bienes jurídicos y libertad individual. Trad. Raúl Pariona Arana. In: MAIER, Julio B. J.; CÓRDOBA, Gabriela E. (Orgs.) ¿Tiene un futuro el Derecho Penal? Buenos Aires: Ad- Hoc, 2009, p.73-90.

- ¿Es la protección de bienes jurídicos una finalidad del Derecho Penal? In: HEFENDEHL. Roland. La teoría del bien jurídico. Trad. María Martín Lorenzo. Madrid: Marcial Pons, 2007, p.443-458.

. Derecho Penal. Parte General. T. I. Fundamentos. La Estructura de la Teoría del Delito. Trad. Diego-Manuel Luzón Peña, Miguel Díaz y García Conlledo e Javier De Vicente Remesal. Madrid: Civitas, 1997.

RUGGIERO, Vincenzo. Crimes e Mercados - Ensaios e Anticriminologia. Rio de janeiro: Lumen Juris, 2008.

SCHÜNEMANN, Bernd. A crítica ao paternalismo jurídico-penal - um trabalho de Sísifo? Trad. Luís Greco. Revista Justiça e Sistema Criminal, v.4, n 7, p.47-70, jul/ dez. 2012.

. O princípio da proteção de bens jurídicos como ponto de fuga dos limites constitucionais e da interpretação dos tipos. Trad. Luís Greco. In: GRECO, Luís; TÓRTIMA, Fernanda (Org.). O bem jurídico como limitação do poder estatal de incriminar? Trad. Luís Greco. Rio de Janeiro: Lumen Juris, 2011.

. El sistema de la teoría del delito. In: SCHÜNEMANN, Bernd. Derecho penal contemporáneo. Sistema y desarrollo. Peligro y límites. Trad. José Milton Peralta. Buenos Aires: Hammurabi, 2010.

STRATENWERTH, Günter. La criminalización en los delitos contra bienes jurídicos colectivos. In: HEFENDEHL. Roland. La teoría del bien jurídico. Trad. María Martín Lorenzo. Madrid: Marcial Pons, 2007, p.365-372.

TAVARES, Juarez. Bien juridico y función en Derecho penal. Trad. Monica Cuñarro. Buenos Aires: Hammurabi, 2004.

WELZEL, Hans. Derecho Penal alemán. Parte General. Trad. Juan Bustos Ramírez e Sergio Yáñez Pérez. Santiago: Editorial Jurídica de Chile, 1976.

ZACCONE, Orlando D’Elia Filho. Indignos de Vida. Rio de Janeiro: Revan, 2015.

ZAFFARONI, Eugênio Raúl. A Palavra dos Mortos - Conferências de Criminologia Cautelar. São Paulo: Saraiva, 2012. 